\title{
HUBUNGAN TINGKAT KEPERCAYAAN DIRI DENGAN INTENSITAS PENGGUNAAN MEDIA SOSIAL WHATSAPP PADA MAHASISWA KEDOKTERAN 2018
}

\author{
Arum Sonia Azahra Nur Annisa1, Istar Yuliadi', Dian Nugroho ${ }^{3}$ \\ 1,2,3Fakultas Kedokteran Universitas Sebelas Maret; Jl. Ir. Sutami No.36 A, Pucangsawit, \\ Kec. Jebres, Kota Surakarta, Jawa Tengah 57126, (0271) 664178 \\ e-mail: 1arumsonia44@gmail.com, 2yuliadiistar@gmail.com, ${ }^{3}$ dianfkuns@staff.uns.ac.id
}

\begin{abstract}
Confidence is the result of the process of identity formation. A clear self identity results in high self confidence. A blurred identity decreases self-confidence. Confidence affects one's ability to communicate and interact with others, which means interpersonal communication. Interpersonal communication among students is quite important in developing self-concept, self-actualization, for survival, to obtain happiness, to avoid pressure and tension. Self-confidence affects interpersonal communication means that self-confidence also affects the way students or adolescents in general communicate with social media. Different confidence in each individual in their teens will affect the intensity of their use of social media. Intensity of use is the level of depth and strength of attitude in using or utilizing social media facilities by paying attention to the duration and frequency of use. This study aims to determine the correlation between the level of self-confidence and the intensity of use of social media. The results show that there is a significant negative correlation between the level of self-confidence and the intensity of using WhatsApp social media for the 2018 FK UNS students.
\end{abstract}

Keywords: Self-confidence, WhatsApp usage intensity.

Abstrak. Kepercayaan diri merupakan hasil dari proses pembentukan identitas. Identitas diri yang jelas menghasilkan kepercayaan diri yang tinggi. Identitas yang kabur menurunkan kepercayaan diri. Kepercayaan diri mempengaruhi kemampuan seseorang berkomunikasi dan berinteraksi dengan orang lain yang berarti komunikasi interpersonal. Komunikasi interpersonal di kalangan mahasiswa cukup penting dalam membangun konsep diri, aktualisasi diri, untuk kelangsungan hidup, untuk memperoleh kebahagiaan, untuk menghindarkan diri dari tekanan dan ketegangan. Kepercayaan diri mempengaruhi komunikasi interpersonal berarti kepercayaan diri juga mempengaruhi cara mahasiswa atau remaja pada umumnya dalam berkomunikasi dengan media sosial. Kepercayaan diri yang berbeda - beda pada setiap individu di usia remaja ini yang akan berpengaruh terhadap intensitas penggunaan media sosial mereka. Intensitas penggunaan merupakan tingkat kedalaman dan kekuatan sikap dalam menggunakan atau memanfaatkan fasilitas-fasilitas media sosial dengan memperhatikan durasi waktu dan frekuensi penggunaannya. Penelitian ini bertujuan untuk mengetahui hubungan antara tingkat kepercayaan diri dan intensitas penggunaan media sosial. Hasil menunjukkan bahwa ada hubungan korelasi signifikan negatif antara tingkat kepercayaan diri dengan intensitas penggunaan media sosial WhatsApp pada mahasiswa FK UNS angkatan 2018.

Kata Kunci: Intensitas penggunaan WhatsApp, Kepercayaan diri.

\section{Pendahuluan}

Seiring berjalannya waktu, tidak dapat dipungkiri perkembangan internet sangat pesat dan meliputi segala aspek kehidupan. Pengaruh internet sangat kuat terutama dalam bidang komunikasi dimana semakin diperlukan media komunikasi yang efektif dan efisien. Kehadiran smartphone yang merupakan salah satu bentuk alat komunikasi yang saat ini banyak digunakan 
oleh masyarakat saat ini semakin mempermudah akses masyarakat terhadap internet. Berkembangnya internet sejalan dengan bermunculannya media sosial sebagai media komunikasi yang multifungsi serta tidak terbatas jarak dan waktu. Salah satunya adalah media sosial yang marak digunakan oleh masyarakat Indonesia adalah aplikasi pesan singkat WhatsApp. Media sosial ini menjadi favorit karena fitur - fiturnya yang mempermudah pengguna dalam berkomunikasi. Pada berbagai kalangan masyarakat, mahasiswa pada umumnya berada dalam usia remaja sehingga akrab dengan perkembangan internet dan aktif menggunakan media sosial. Media sosial pesan singkat WhatsApp sejalan dengan media sosial lainnya menjadi media komunikasi interpersonal utama pada mahasiswa.

Kepercayaan diri merupakan hasil dari pencarian identitas diri pada remaja dan sangat berpengaruh terhadap komunikasi interpersonal pada remaja tersebut. Komunikasi interpersonal di kalangan mahasiswa cukup penting dalam membangun konsep diri, aktualisasi diri, untuk kelangsungan hidup, untuk memperoleh kebahagiaan, untuk menghindarkan diri dari tekanan dan ketegangan (Mulyana, 2007). Hal ini dikarenakan pada umumnya mahasiswa terdiri dari usia remaja hingga dewasa muda. Masa remaja merupakan masa peralihan dari masa kanak-kanak menuju masa dewasa (Santrock, 2003). Masa peralihan ini melibatkan perubahan secara biologis, kognitif, dan sosioemosional (Santrock, 2003). Remaja awal mengalami perkembangan psikososial. Perkembangan psikososial adalah proses pencarian identitas diri (Papalia, Olds, \& Feldman, 2008). Kepercayaan diri merupakan hasil dari proses pembentukan identitas. Identitas diri yang jelas menghasilkan kepercayaan diri yang tinggi. Identitas yang kabur menurunkan kepercayaan diri. Kepercayaan diri mempengaruhi kemampuan seseorang berkomunikasi dan berinteraksi dengan orang lain (Stets dan Burke, 2014). Kepercayaan diri mempengaruhi komunikasi interpersonal berarti kepercayaan diri juga mempengaruhi cara mahasiswa atau remaja pada umumnya dalam berkomunikasi dengan media sosial.

Media sosial sebagai media komunikasi interpersonal sangat bergantung terhadap karakter penggunaannya. Penggunaan internet yang berlebihan mengakibatkan dampak buruk berupa bertambahnya komunikasi secara tidak langsung (non-face to face communication). Seseorang dengan kepercayaan diri yang tinggi berani untuk berkomunikasi sacara langsung, berbanding terbalik dengan individu yang memiliki kepercayaan diri rendah, mereka akan cenderung takut atau tidak bisa mempertahankan komunikasi secara langsung dalam waktu yang lama. Harga diri relatif tinggi di masa kanak-kanak, turun selama masa remaja, naik secara bertahap sepanjang masa dewasa sebelum cenderung menurun di usia tua (Orth \& Robins, 2013; Robins \& Trzesniewski, 2005). Kepercayaan diri yang berbeda - beda pada setiap individu di usia remaja ini yang akan berpengaruh terhadap intensitas penggunaan media sosial mereka. Intensitas penggunaan merupakan tingkat kedalaman dan kekuatan sikap dalam menggunakan atau memanfaatkan fasilitas-fasilitas media sosial dengan memperhatikan durasi waktu dan frekuensi penggunaannya. 
Penelitian yang menghubungkan antara kepercayaan diri dan media sosial yang pertama kali dilakukan di University of Strathcylde, Ohio University dan University of lowa melakukan survei atas 881 pelajar di Amerika Serikat (Pikiran Rakyat, 2014). Berdasarkan penelitian tersebut ditemukan hubungan antara waktu yang dihabiskan di media sosial dengan perbandingan negatif mengenai kesan tubuh. Penelitian Lenhart dan Madden (2006) menunjukkan bahwa remaja dengan kepercayaan diri tinggi tetap menggunakan media sosial dengan intensitas yang tinggi untuk memelihara dan mengatur pertemanan yang sudah terjalin secara sosial (secara tatap muka). Pada penelitian yang dilakukan oleh Hafidz Azizan (2016), ditemukan responden yang memiliki kepercayaan diri dengan kategori tinggi sebanyak 48\% atau setara dengan 67 responden, kategori sedang sebanyak 52\% atau setara dengan 72 responden, dan kategori rendah sebanyak $0 \%$ atau setara dengan 0 responden. Terdapat responden yang memiliki ketergantungan sosial media dengan kategori tinggi sebanyak 15\% atau setara dengan 20 responden, kategori sedang sebanyak 69\% atau setara dengan 95 responden, dan kategori rendah sebanyak $16 \%$ atau setara dengan 22 responden. Sehingga pada penelitian ini ditemukan pengaruh yang sangat signifikan antara kepercayaan diri dengan ketergantungan media sosial pada siswa SMK N 1 Bantul, sehingga dapat diartikan kepercayaan diri memprediksikan ketergantungan media sosial sebesar $22 \%$.

Menurut data yang dikeluarkann oleh We Are Social pada bulan Januari 2019, aplikasi WhatsApp menduduki peringkat pertama pengguna media sosial messenger terbanyak di dunia dengan total pengguna aktif sebanyak 1,5 miliar, selanjutnya terdapat FB Messenger dengan total pengguna aktif sebanyak 1,3 miliar, WeChat dengan total pengguna aktif sebanyak 1,083 miliar, dan Line dengan total pengguna aktif sebanyak 194 juta. Sedangkan di Indonesia sendiri, WhatsApp juga menduduki peringkat pertama dengann total pengguna aktif sebanyak $83 \%$ dari total pengguna internet, selanjutnya terdapat Line dengan total pengguna aktif sebanyak 59\%, dan FB Messenger dengan total pengguna aktif sebanyak 47\% (WeAreSocial [WAS], 2019). Sekolah Tinggi Sandi Negara (STSN) bersama Yahoo! melakukan riset mengenai penggunaan internet di kalangan remaja, yang hasilnya menunjukkan kalangan remaja usia 15-19 tahun mendominasi pengguna internet di Indonesia sebanyak 64\% (Hanafebria, 2014). Sejalan dengan hasil survei yang dilakukan oleh APJII (2017), ditemukan pengguna internet Indonesia terbanyak adalah kelompok usia remaja yaitu usia 13 - 18 tahun sebanyak 75,50\% dan usia 19 34 tahun sebanyak 74,23\% yang dimana mahasiswa termasuk didalamnya. (APJII, 2017). Berdasarkan hasil riset tersebut dapat disimpulkan bahwa media sosial online terutama WhatsApp sangat menarik perhatian terutama kalangan remaja.

Survei pendahuluan yang telah dilakukan peneliti pada subjek target mahasiswa Fakultas Kedokteran Universitas Sebelas Maret tahun angkatan 2018 sebanyak 10 orang. Setelah didapatkan data menggunakan kuesioner kepercayaan diri Lauster dan kuesioner Social Networking Time Usage Scale (SONTUS), didapatkan 4 mahasiswa memiliki tingkat 


\section{WACANA}

kepercayaan diri sedang dan 6 mahasiswa memiliki tingkat kepercayaan diri tinggi. Sedangkan untuk intensitas penggunaan media sosial, didapatkan 6 mahasiswa dengan intensitas penggunaan media sosial WhatsApp rendah, 1 mahasiswa dengan intensitas penggunaan media sosial WhatsApp sedang, dan 3 mahasiswa dengan intensitas penggunaan media sosial WhatsApp tinggi. Setelah dilakukan uji coba dengan statistik didapatkan hubungan yang kuat antara tingkat kepercayaan diri dan intensitas penggunaan media sosial WhatsApp. Berdasarkan survei pendahuluan dan pemaparan diatas maka peneliti tertarik untuk meneliti "Hubungan Tingkat Kepercayaan Diri dengan Intensitas Penggunaan Media Sosial Aplikasi Pesan Singkat WhatsApp pada Mahasiswa Program Studi Pendidikan Dokter Fakultas Kedokteran Universitas Sebelas Maret Surakarta Angkatan 2018." , dengan hipotesis “Terdapat hubungan tingkat kepercayaan diri dengan intensitas penggunaan media sosial WhatsApp pada mahasiswa Program Studi Kedokteran Fakultas Kedokteran Universitas Sebelas Maret Surakarta Angkatan 2018."

\section{Metode Penelitian}

Total subjek penelitian yang diolah pada penelitian ini adalah 60 subjek. Karakteristik subjek penelitian dapat dilihat pada tabel 4.1, 4.2, 4.3, dan 4.4.

Tabel 1. Karakteristik subjek penelitian.

\begin{tabular}{lll}
\hline Data Partisipan & & Frekuensi \\
\hline Usia (Tahun) & 17 & 2 \\
& 18 & 13 \\
& 19 & 35 \\
& 20 & 9 \\
Jenis Kelamin & 21 & 1 \\
& Laki-laki & 17 \\
Uang saku/pendapatan per bulan (Rp) & Perempuan & 43 \\
& $<500.000$ & 3 \\
& $500.000-1.000 .000$ & 17 \\
& $1.000 .000-2.000 .000$ & 31 \\
\hline
\end{tabular}

Pada tabel 1. dapat dilihat bahwa dari 60 orang responden penelitian ini yang berusia antara 17-21 tahun, mayoritas berusia 19 tahun yaitu sejumlah 35 orang. Jumlah responden perempuan lebih banyak (43 orang) daripada jumlah responden laki-laki (17 orang) dengan 
selisih yang cukup jauh. Mayoritas responden memiliki jumlah uang saku/pendapatan per bulan Rp 1.000.000,00-Rp 2.000.000,00 yaitu sebanyak 31 orang.

Tabel 2. Tabel karakteristik subjek penelitian berdasarkan usia dan intensitas penggunaan media sosial WhatsApp $(\mathrm{n}=60)$.

\begin{tabular}{lllll}
\hline Karakteristik sampel & & \multicolumn{3}{c}{ Intensitas Penggunaan Media Sosial Whatsapp } \\
Usia (tahun) & Rendah & Sedang & Tinggi & Sangat Tinggi \\
\hline 17 & 1 & 0 & 1 & 0 \\
18 & 4 & $\mathbf{5}$ & 4 & 0 \\
19 & $\mathbf{2 0}$ & $\mathbf{5}$ & $\mathbf{1 0}$ & 0 \\
20 & 2 & 3 & 4 & 0 \\
21 & 0 & 1 & 0 & 0 \\
\hline
\end{tabular}

Dari tabel 2. dapat dilihat bahwa pada intensitas penggunaan media sosial WhatsApp rendah didominasi oleh responden dengan usia 19 tahun (20 orang), pada intensitas sedang didominasi oleh responden dengan usia 18 tahun (5 orang) dan 19 tahun (5 orang), sedangkan pada intensitas tinggi didominasi oleh usia 19 tahun (10 orang).

Tabel 3. Tabel karakteristik subjek penelitian berdasarkan uang saku atau pendapatan per bulan dan intensitas penggunaan media sosial WhatsApp $(n=60)$.

\begin{tabular}{lllll}
\hline $\begin{array}{l}\text { Karakteristik sampel } \\
\text { Uang saku }\end{array}$ & \multicolumn{2}{l}{ Populasi Sampel (Intensitas Penggunaan Media Sosial Whatsapp) } \\
$\begin{array}{l}\text { pendapatan per bulan } \\
\text { R500.000 }\end{array}$ & Rendah & Sedang & Tinggi & Sangat Tinggi \\
$500.000-1.000 .000$ & 9 & 0 & 2 & 0 \\
$1.000 .000-2.000 .000$ & $\mathbf{1 0}$ & 5 & 3 & 0 \\
$>2.000 .000$ & 7 & $\mathbf{8}$ & $\mathbf{1 3}$ & 0 \\
\hline
\end{tabular}

Dari tabel 3. dapat dilihat bahwa pada intensitas penggunaan media sosial WhatsApp rendah, sedang, dan tinggi didominasi oleh responden dengan uang saku/pendapatan per bulan $\mathrm{Rp} 1.000 .000,00-\mathrm{Rp} 2.000 .000,00$ (rendah = 10 orang, sedang = 8 orang, dan tinggi $=13$ orang).

Tabel 4. Tabel karakteristik subjek penelitian berdasarkan tingkat kepercayaan diri dan intensitas penggunaan media sosial WhatsApp $(n=60)$. 


\begin{tabular}{lllll}
\hline Karakteristik sampel & \multicolumn{3}{c}{ Intensitas Penggunaan Media Sosial Whatsapp } \\
Tingkat Kepercayaan Diri & Rendah & Sedang & Tinggi & Sangat Tinggi \\
\hline Rendah & 0 & 0 & 0 & 0 \\
Sedang & $\mathbf{1 7}$ & $\mathbf{1 9}$ & $\mathbf{1 4}$ & 0 \\
Tinggi & 10 & 0 & 0 & 0 \\
\hline
\end{tabular}

Dari tabel 4. dapat dilihat bahwa pada intensitas penggunaan media sosial WhatsApp rendah, sedang, dan tinggi didominasi oleh responden dengan tingkat kepercayaan diri sedang (rendah $=17$ orang, sedang $=19$ orang, dan tinggi $=14$ orang).

Data yang didapatkan diolah menggunakan analisis uji korelasi Rank Spearman untuk mencari tahu hubungan karakteristik responden terhadap intensitas penggunaan media sosial aplikasi pesan singkat WhatsApp. Hasil penelitian dapat dilihat pada tabel 4.5.

Tabel 5. Hubungan intensitas penggunaan media sosial aplikasi pesan singkat WhatsApp dengan variabel bebas (tingkat kepercayaan diri) dan variabel perancu (usia dan uang saku/pendapatan per bulan).

\begin{tabular}{lcc}
\hline Hubungan Intensitas Penggunaan Media Sosial & $\mathrm{r}$ & $\mathrm{p}$ \\
Whatsapp dengan & & $\mathbf{0 , 0 0 0}$ \\
\hline Tingkat Kepercayaan Diri & $\mathbf{- 0 , 4 5 8}$ & 0,814 \\
Usia & 0,31 & 0,604 \\
Uang saku/pendapatan per bulan & $-0,68$ & \\
\hline
\end{tabular}

Pada hubungan antara kepercayaan diri dengan intensitas penggunaan media sosial WhatsApp didapatkan hasil koefisien korelasi $(r)=-0,458$ yang berarti kedua variabel berkorelasi kuat namun tidak searah dan hasil signifikansi $(\mathrm{p})=0,000$ yang berarti hubungan kedua variabel signifikan secara statistik. Sedangkan pada hubungan antara variabel perancu berupa usia pada intensitas penggunaan media sosial WhatsApp didapatkan hasil $(\mathrm{r})=0,31$ yang berarti kedua variabel berkorelasi cukup dan searah namun dari hasil $(\mathrm{p})$ didapatkan hasil 0,814 yang berarti hubungan antara keduanya tidak signifikan secara statistik. Pada hubungan antara variabel perancu jumlah uang saku/pendapatan per bulan dengan intensitas penggunaan media sosial didapatkan hasil $(r)=-0,68$ yang berarti kedua variabel berkorelasi kuat dan tidak searah, namun hubungan keduanya juga tidak signifikan karena didapatkan nilai $\mathrm{p}=0,604$. 


\section{Tabel dan Gambar}

Tabel 1. Skala The Test of Self Confidence Lauster

\begin{tabular}{|c|c|c|c|}
\hline \multirow[b]{2}{*}{ Aspek } & \multicolumn{2}{|c|}{ Aitem } & \multirow[t]{2}{*}{ Jumlah } \\
\hline & Favorable & Unfavorable & \\
\hline $\begin{array}{l}\text { Keyakinan akan kemampuan diri (Sikap postif } \\
\text { seseorang terhadap dirinya) }\end{array}$ & - & $1,5,6,13$ & 4 \\
\hline $\begin{array}{l}\text { Optimis (Selalu berpandangan baik dalam } \\
\text { menghadapi segala hal) }\end{array}$ & 10 & $7,12,14,15$ & 5 \\
\hline $\begin{array}{l}\text { Objektif (Memandang sesuatu dengan } \\
\text { kebenaran yang semestinya) }\end{array}$ & - & 16 & 1 \\
\hline $\begin{array}{l}\text { Bertanggung jawab (Menanggung sesuatu yang } \\
\text { telah menjadi konsekuensinya) }\end{array}$ & 9 & 2 & 2 \\
\hline $\begin{array}{l}\text { Rasionalitas dan realitas (Menganalisa masalah } \\
\text { atau kejadian dengan menggunakan pikiran } \\
\text { yang masuk akal) }\end{array}$ & - & $3,4,8,11$ & 4 \\
\hline Jumlah Aitem & & & 16 \\
\hline
\end{tabular}

Sumber : (Rohmah, 2017)

Tabel 2. Skor Komponen pada Kuesioner Social Network Time Usage Scale (SONTUS)

Jumlah Skor Pertanyaan

Komponen 1

Skor Komponen 1

$\begin{array}{ll}9-12 & 1 \\ 13-16 & 2 \\ 17-20 & 3 \\ 21-24 & 4 \\ 25-28 & 5 \\ 29-32 & 6 \\ >32 & 7\end{array}$

Jumlah Skor Pertanyaan 


\begin{tabular}{ll} 
Komponen 2 & Skor Komponen 2 \\
\hline $6-9$ & 1 \\
$10-13$ & 2 \\
$14-17$ & 3 \\
$18-21$ & 4 \\
$>32$ & 5 \\
\hline
\end{tabular}

\section{Jumlah Skor Pertanyaan}

\section{Komponen $3 \quad$ Skor Komponen 3}

\begin{tabular}{lc}
\hline $5-8$ & 1 \\
$9-12$ & 2 \\
$13-16$ & 3 \\
$17-20$ & 4 \\
\hline
\end{tabular}

\section{Jumlah Skor Pertanyaan}

Komponen $4 \quad$ Skor Komponen 4

\begin{tabular}{ll}
\hline $5-8$ & 1 \\
$9-12$ & 2 \\
$13-16$ & 3 \\
$17-20$ & 4 \\
\hline
\end{tabular}

\section{Jumlah Skor Pertanyaan}

\section{Komponen 5}

Skor Komponen 5

\begin{tabular}{ll}
\hline $4-7$ & 1 \\
$8-11$ & 2 \\
$>11$ & 3 \\
\hline
\end{tabular}

Sumber: (Olufadi, 2015)

Tabel 3. Skor Global dan Intensitas Penggunaan Situs Jejaring Sosial

\begin{tabular}{ll} 
Skor Global & IntensitasPenggunaan \\
\hline $\mathbf{5 - 9}$ & Rendah
\end{tabular}

10-14 Sedang

15-19 Tinggi

$>19 \quad$ Sangat Tinggi

Tabel 4. Karakteristik subjek penelitian. 


\begin{tabular}{lll}
\hline Data Partisipan & & Frekuensi \\
\hline Usia (Tahun) & 17 & 2 \\
& 18 & 13 \\
& 19 & 35 \\
Jenis Kelamin & 20 & 9 \\
& 21 & 1 \\
Uang saku/pendapatan per bulan (Rp) & Laki - laki & 17 \\
& Perempuan & 43 \\
& $<500.000$ & 3 \\
& $500.000-1.000 .000$ & 17 \\
& $1.000 .000-2.000 .000$ & 31 \\
& $>2.000 .000$ & 9 \\
\hline
\end{tabular}

Tabel 5. Tabel karakteristik subjek penelitian berdasarkan usia dan intensitas penggunaan media sosial WhatsApp $(n=60)$.

\begin{tabular}{lllll}
\hline Karakteristik sampel & & \multicolumn{3}{c}{ Intensitas Penggunaan Media Sosial Whatsapp } \\
Usia (tahun) & Rendah & Sedang & Tinggi & Sangat Tinggi \\
\hline 17 & 1 & 0 & 1 & 0 \\
18 & 4 & $\mathbf{5}$ & 4 & 0 \\
19 & $\mathbf{2 0}$ & $\mathbf{5}$ & $\mathbf{1 0}$ & 0 \\
20 & 2 & 3 & 4 & 0 \\
21 & 0 & 1 & 0 & 0 \\
\hline
\end{tabular}

Tabel 6. Tabel karakteristik subjek penelitian berdasarkan uang saku atau pendapatan per bulan dan intensitas penggunaan media sosial WhatsApp $(n=60)$.

\begin{tabular}{lllll}
\hline $\begin{array}{l}\text { Karakteristik sampel } \\
\text { Uang saku / pendapatan } \\
\text { per bulan }\end{array}$ & \multicolumn{2}{c}{ Populasi Sampel (Intensitas Penggunaan Media Sosial Whatsapp) } \\
& Rendah & Sedang & Tinggi & Sangat Tinggi \\
\hline$<500.000$ & 1 & 0 & 2 & 0 \\
$500.000-1.000 .000$ & 9 & 5 & 3 & 0 \\
$1.000 .000-2.000 .000$ & $\mathbf{1 0}$ & $\mathbf{8}$ & $\mathbf{1 3}$ & 0 \\
$>2.000 .000$ & 7 & 1 & 1 & 0 \\
\hline
\end{tabular}

Tabel 7. Tabel karakteristik subjek penelitian berdasarkan tingkat kepercayaan diri dan intensitas penggunaan media sosial WhatsApp $(n=60)$. 
WACANA

\begin{tabular}{lllll}
\hline Karakteristik sampel & \multicolumn{4}{c}{ Intensitas Penggunaan Media Sosial Whatsapp } \\
Tingkat Kepercayaan Diri & Rendah & Sedang & Tinggi & Sangat Tinggi \\
\hline Rendah & 0 & 0 & 0 & 0 \\
Sedang & $\mathbf{1 7}$ & $\mathbf{1 9}$ & $\mathbf{1 4}$ & 0 \\
Tinggi & 10 & 0 & 0 & 0 \\
\hline
\end{tabular}

Tabel 8. Hubungan intensitas penggunaan media sosial aplikasi pesan singkat WhatsApp dengan variabel bebas (tingkat kepercayaan diri) dan variabel perancu (usia dan uang saku/pendapatan per bulan).

\begin{tabular}{lccc}
\hline Hubungan Intensitas Penggunaan Media Sosial & $\mathrm{r}$ & $\mathrm{p}$ \\
Whatsapp dengan & & & $\mathbf{0 , 0 0 0}$ \\
\hline Tingkat Kepercayaan Diri & $\mathbf{- 0 , 4 5 8}$ & 0,814 \\
Usia & 0,31 & 0,604 \\
Uang saku/pendapatan per bulan & $-0,68$ & \\
\hline
\end{tabular}
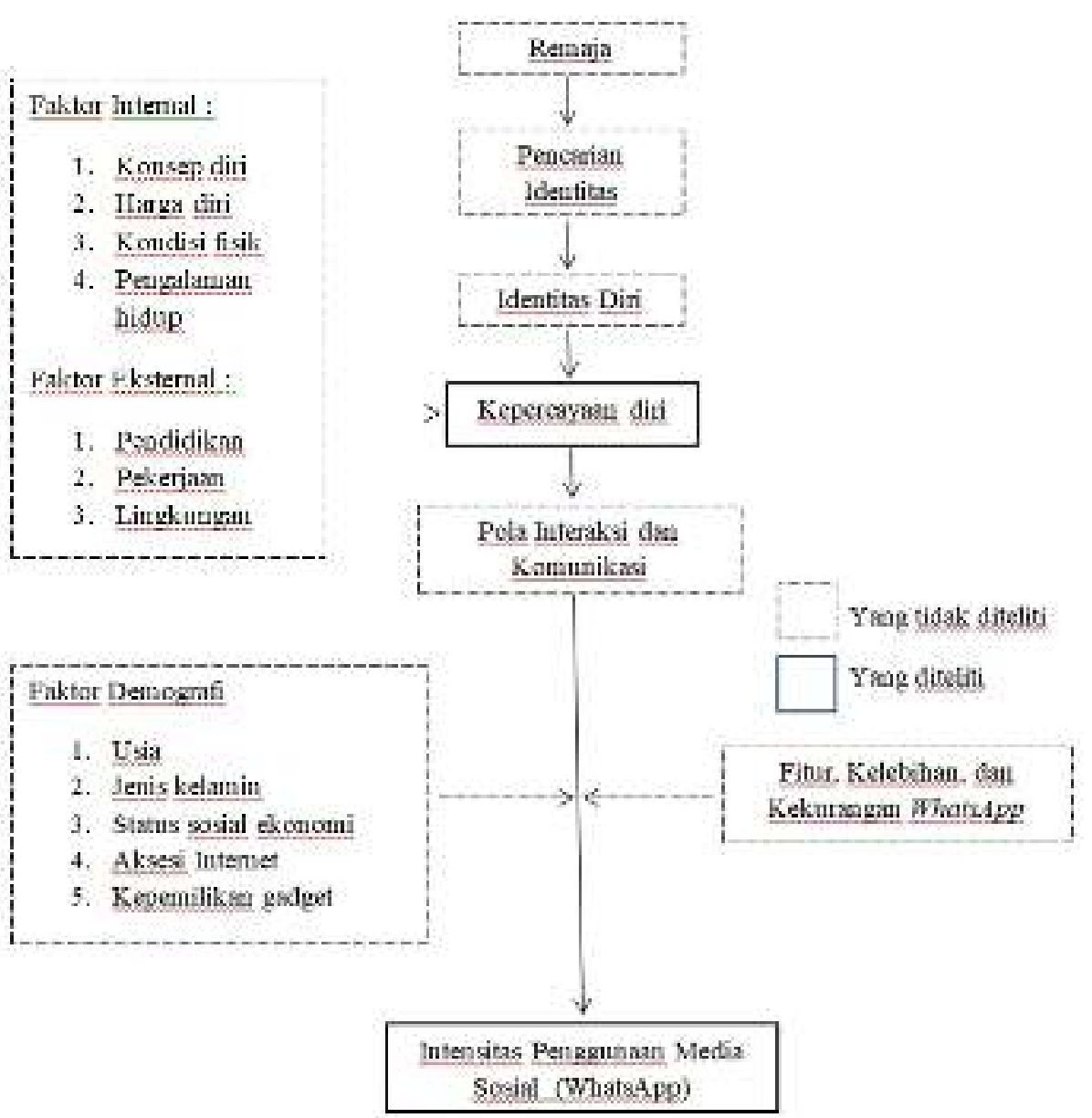

Gambar 1. Kerangka Pemikiran 


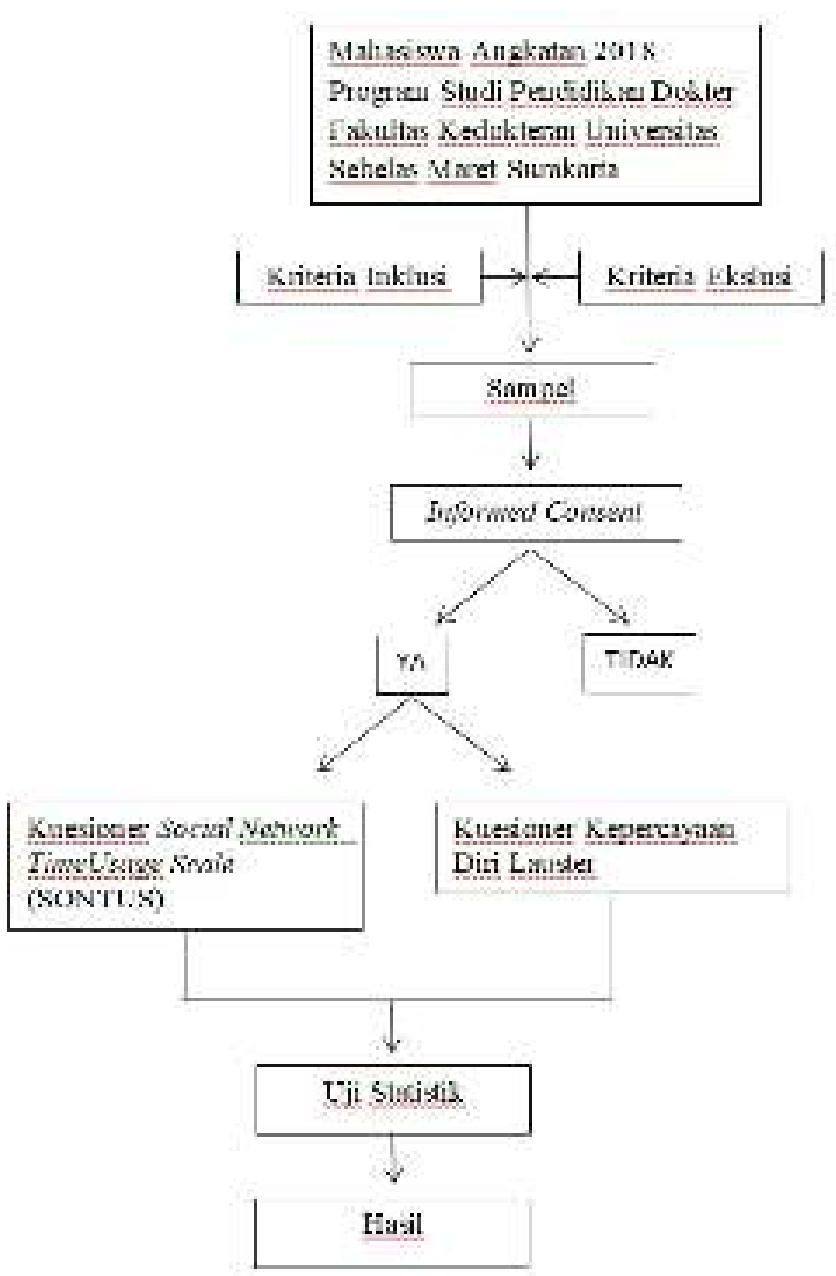

Gambar 2. Alur Penelitian

\section{Diskusi}

Berdasarkan analisis uji hipotesis menggunakan korelasi Spearman yang telah dilakukan (tabel 4.5), didapatkan bahwa ada hubungan korelasi signifikan negatif antara tingkat kepercayaan diri dengan intensitas penggunaan media sosial WhatsApp pada mahasiswa FK UNS angkatan 2018. Hasil analisa data menunjukkan nilai koefisien korelasi (r) -0,458 dan nilai signifikan (p) 0,000<0,05. Sehingga dapat diartikan bahwa intensitas penggunaan media sosial WhatsApp dapat dipengaruhi oleh tingkat kepercayaan diri dan sebaliknya. Semakin tinggi tingkat kepercayaan diri seseorang maka semakin rendah intensitas orang tersebut menggunakan media sosial WhatsApp. 
Hal ini sesuai dengan penelitian sebelumnya yang dilakukan pada 200 mahasiswa dengan rata-rata usia 19 tahun yang secara aktif menggunakan Instant Messaging atau aplikasi pesan singkat, pada penelitian ini didapatkan hasil bahwa mahasiswa dengan kepercayaan diri yang rendah memiliki tendensi untuk mengalami kecanduan media sosial atau aplikasi pesan singkat dibandingkan dengan mahasiswa dengan kepercayaan diri tinggi (Ehrenberg et al., 2008). Pada penelitian yang dilakukan oleh Steinfield et al. (2008), didapatkan hasil bahwa pada responden dengan kepercayaan diri dan kepuasan pada hidup yang tinggi, intensitas penggunaan media sosialnya rendah. Sedangkan pada penelitian yang dilakukan di dalam negeri pada 100 mahasiswa, didapatkan adanya hubungan negatif yang kuat antara kepercayaan diri dengan frekuensi mengakses situs jejaring sosial (Ranggamukti, 2011). Pada ketiga penelitian diatas dan penelitian yang dilakukan peneliti memiliki kesimpulan bahwa individu dengan kepercayaan diri rendah memiliki tendesi untuk memiliki intensitas penggunaan media sosial yang tinggi.

Hasil penelitian ini bertentangan dengan penelitian yang dilakukan oleh Lenhart dan Madden (2006), pada penelitian tersebut didapatkan hasil bahwa remaja dengan kepercayaan diri tinggi tetap menggunakan media sosial dengan intensitas yang tinggi untuk memelihara dan mengatur pertemanan yang sudah terjalin secara sosial (secara tatap muka). Sedangkan pada penelitian Baker dan White (2010), kepercayaan diri termasuk dalam faktor yang mempengaruhi intensitas mengakses media sosial namun tidak signifikan, faktor yang paling signifikan yaitu tujuan responden dalam mengakses media sosial. Pada penelitian dengan hasil bertentangan diatas, ditemukan bahwa justru pada individu dengan kepercayaan diri tinggi memiliki intensitas penggunaan media sosial yang tinggi pula untuk melanjutkan komunikasi yang telah berjalan secara tatap muka.

Kepercayaan diri merupakan suatu keyakinan seseorang terhadap segala aspek kelebihan yang dimilikinya, dengan keyakinan tersebut seseorang merasa mampu untuk mencapai berbagai tujuan di dalam hidupnya. (Hakim, 2002). Individu dengan tingkat kepercayaan diri yang tinggi lebih mudah dalam berinteraksi sosial sehingga tidak mengalami kesulitan dalam menjalin relasi dengan orang lain, serta mampu beradaptasi dengan orang ataupun situasi lain secara cepat dan tepat (Wood, Heimpel, Michela, dalam Rini, 2002). Individu dengan kepercayaan diri yang tinggi cenderung memiliki keyakinan terhadap dirinya sendiri sehingga lebih mudah berinteraksi dalam masyarakat.

Hal sebaliknya terjadi pada individu dengan tingkat kepercayaan diri rendah, mereka menunjukkan perilaku pesimis dan memandang segala situasi yang dihadapinya secara negatif (Rini, 2002). Pandangan yang negatif ini mengakibatkan individu dengan kepercayaan diri yang rendah cenderung melihat lingkungan sebagai sesuatu yang tidak menarik dan mengakibatkan perasaan tidak suka. Kepercayaan diri sangat berpengaruh terhadap penyesuaian diri remaja, sehingga mahasiswa yang juga termasuk dalam kelompok usia remaja akhir dan dewasa muda yang memiliki tugas perkembangan untuk menjalin relasi juga dipengaruhi oleh kepercayaan 
diri, jika proses menjalin relasi ini berhasil maka akan menimbulkan keintiman, namun bila gagal akan mengakibatkan isolasi yang menimbulkan perasaaan kesepian dan menarik diri dari lingkungan karena menganggap dirinya tidak mampu bergaul (Erikson, dalam Santrock, 1994). Individu dengan kepercayaan diri yang rendah tidak yakin dengan kemampuan dan dirinya sendiri sehingga cenderung sulit beradaptasi dengan lingkungan baru.

Tanggapan lingkungan sekitar ini yang menyebabkan individu merasa dikucilkan dan cenderung memilih untuk menjauhkan diri dari lingkungan. Hal ini menyebabkan individu memiliki pandangan negatif terhadap lingkungan yang sering menimbulkan kecemasan. Kecemasan terhadap lingkungan dan situasi sosial di dalamnya mengakibatkan individu menggunakan situs jejaring sosial sebagai media untuk melakukan interaksi sosial. Hal ini disebabkan karena individu dengan tingkat kepercayaan diri rendah tetap perlu untuk melakukan interaksi sosial dalam menjalani kehidupan sehari-hari namun individu tersebut merasa tidak nyaman dengan interaksi langsung secara tatap muka, sehingga situs jejaring sosial pun kerap menjadi solusinya (Sparaggins, 2009). Pada akhirnya individu dengan kepercayaan diri rendah beralih ke komunikasi dengan media sosial dibanding dengan tatap muka.

Ciri lain dari individu dengan kepercayaan diri rendah adalah cenderung mengubah sikap dan perilakunya agar mendapat pengakuan dan penerimaan dari lingkungannya (Rini, 2002). Individu dengan kepercayaan diri rendah memaksakan diri untuk mengikuti dan beradaptasi dengan nilai dan tuntutan yang ada dalam kelompok meskipun hal tersebut tidak sesuai dengan nilai pribadi individu tersebut (Hurlock, 1990). Individu pada masa ini mengahadapi beberapa pilihan sulit, salah satunya ketika menghadapai kenyataan bahwa dirinya harus mengadopsi nilai-nilai yang ada pada sebuah kelompok untuk dapat diterima masuk sebagai anggota keompok tersebut. Perilaku konformis terhadap norma kelompok ini, sebagaimana dikatakan oleh Baker, Rosland, dan White (2010), merupakan salah satu faktor yang mempengaruhi frekuensi mengakses situs jejaring sosial. Untuk menghindari kecemasan dan ketidaknyamanan untuk memaksakan diri menjadi orang lain, individu dengan kepercayaan diri rendah menggunakan media sosial untuk berinteraksi dalam masyarakat.

Salah satu aspek dalam kepercayaan diri adalah rasa aman (Lauster, 2012). Individu yang kurang memiliki kepercayaan diri memiliki perasaan tidak aman terhadap lingkungannya, hal ini kemudian menimbulkan rasa takut dan ragu-ragu saat mengahadapi lingkungan sosialnya. Hal ini sesuai dengan salah satu karakteristik individu yang kepercayaan dirinya rendah, yaitu cenderung mengindari pengambilan resiko karena memiliki ketakutan akan kegagalan. Kedua hal tersebut mengakibatkan individu dengan kepercayaan diri yang rendah kemudian cenderung menghindar dari situasi sosial. Penghindaran dari situasi sosial semacam ini serupa dengan apa yang dilakukan individu yang gagal pada masa perkembangan dewasa awal. Individu yang pada masa ini umumnya berstatus sebagai mahasiswa, mengalami masa, yang 
menurut Erikson (dalam Santrock, 1994), dikatakan sebagai masa keintiman versus isolasi. Masa ini adalah masa di mana individu belajar untuk berelasi dan menjalin komitmen dengan orang lain, kegagalan pada masa ini dapat mengakibatkan individu tidak memiliki kepercayaan diri untuk berinteraksi dengan lingkungannya, dan cenderung untuk menarik diri dari lingkungannya.

Aspek lain yang dipengaruhi oleh kepercayaan diri adalah rasa yakin terhadap diri sendiri. Individu yang kurang memiliki kepercayaan diri, memiliki keyakinan pada diri sendiri yang rendah sehingga individu tersebut mudah terpengaruh oleh orang lain dan hal ini mengakibatkan individu tersebut tidak percaya bahwa dirinya mampu menghadapi situasi sosial yang ada di sekitarnya (Beatrik, 2009). Hal ini serupa dengan yang dikatak Erikson (dalam Santrock, 1994) mengenai masa dewasa awal. Masa ini pada umumnya dilalui dengan status sebagai mahasiswa, pada masa ini individu belajar untuk menjalin relasi dengan orang lain, namun sebelum individu dapat melakukan hal itu, ia harus lebih dahulu mengerti tentang dirinya sehingga ketika ia mengerti, maka akan timbul keyakinan pada dirinya. Hal ini berguna sebagai modal untuk menjalin relasinya kemudian.

Dari beberapa deskripsi mengenai individu yang memiliki kepercayaan rendah di atas, menunjukkan bahwa individu yang memiliki kepercayaan diri yang rendah melihat situasi di luar dirinya sebagai hal yang negatif, tidak mampu menghadapi penolakan sehingga cenderung memaksakan diri untuk menganut nilai-nilai yang ada dalam kelompok meskipun tidak mejadi dirinya sendiri, menghindar dari situasi sosial yang menyulitkan, dan meragukan dirinya mampu menghadapi situasi sosialnya dengan baik. Hal-hal tersebut membuat individu memiliki kecemasan pada lingkungan sosialnya. Sparaggins (2009) dalam penelitiannya menjelaskan bahwa kecemasan terhadap situasi sosial adalah prediktor dalam penggunaan situs jejaring sosial yang bermasalah. Hal ini didukung dengan pernyataan Caplan (2005) yang menjelaskan bahwa kecemasan terhadap situasi sosial terbentuk oleh hasrat untuk membangun impresi positif dalam situasi sosial, namun hal ini terhambat dengan kurangnya rasa percaya diri. Individu beralih ke media sosial untuk menghindari kecemasan sosial yang dirasakan dalam hubungan tatap muka, namun tanpa disadari sebenarnya di dalam komunikasi dengan media sosial pun akan menghasilkan kecemasan sosial yang lain.

Orang yang memiliki kecemasan sosial pada umumnya memiliki kemampuan sosial yang kurang baik dan cenderung untuk memilih untuk berinteraksi sosial menggunkan media sosial daripada interaksi sosial secara tatap muka (Caplan, 2005). Hal ini yang menyebabkan individu dengan kepercayaan diri rendah memiliki intensitas akses media sosial yang lebih tinggi dibanding individu dengan kepercayaan diri tinggi. Pada penelitian yang dilakukan oleh Wood, Heimpel, Michela (dalam Rini, 2002), salah satu indikator bahwa seseorang yang memiliki kepercayaan diri yang rendah adalah kurang mampu berinteraksi secara sosial. Salah satu kompensasi dari hal ini adalah dengan menggunakan internet, khususnya situs jejaring sosial 
sebagai media untuk melakukan interaksi, dengan alasan cara ini dianggap lebih tidak mengancam daripada interaksi secara tatap muka. Hal-hal yang disebutkan diatas sesuai dengan hipotesis yang diajukan dan hasil yang didapatkan dari penelitian ini. Berikut peneliti akan menambahkan dampak dari penggunaan media sosial.

Rasa nyaman dalam menggunakan media sosial ini yang dapat mengarah pada kecanduan atau yang termasuk dalam Internet Addiction Disorder. Hal ini disebabkan karena tujuan individu dengan kepercayaan diri rendah dalam menggunakan media sosial adalah karena terdapat kecemasan dalam melakukan interaksi sosial secara langsung. Tanpa disadari bahwa interaksi sosial menggunakan media sosial pun akan mendatangkan kecemasan. Namun individu tidak dapat terlepas dari media sosial akibat kenyamanan dalam penggunaannya. Individu merasa bahwa media sosial membuatnya tetap dapat terhubung dengan lingkungan tanpa bertemu secara langsung (Kurniasih, 2017). Hal ini yang akan memperbesar kemungkinan individu mengalami kecanduan dan susah membedakan hubungan online dan offline.

Jahanian dan Seifury (2013) menyatakan adanya hubungan yang signifikan antara adiksi media sosial dengan kesehatan mental mahasiswa sehingga mereka menyarankan untuk membatasi frekuensi dalam mengakses media sosial. Penelitian yang dilakukan Kubey, Lavin, dan Barrow (2001) juga menyatakan bahwa adiksi media sosial mempengaruhi pencapaian akademik mahasiswa, mahasiswa menjadi depresi karena adanya perasaan kesepian, rasa malu, lelah, dan sulit tidur yang disebabkan oleh kecanduan media sosial. Kecanduan media sosial juga menyebabkann individu menghindari tanggung jawab sosialnya, mengisolasi diri sendiri, kehilangan dukungan sosial dari lingkungan di kehidupan nyata, tidak efisien dalam bekerja, dan menunjukkan performa buruk dalam pendidikan (Moidfar dan Gatabi, 2011). Walaupun tidak dilihat sebagai kelainan psikiatrik yang spesifik dalam edisi terbaru ICD, para ahli menamakan kecanduan media sosial sebagai "Social Networking Site Addiction". Para ahli berpendapat bahwa kecanduan media sosial mungkin dikenali sebagai kelainan mental terutama setelah kecanduan video game dimasukkan ke dalam subkategori dari addiction pada tahun 2018 oleh World Health Organization. Beberapa tanda addictive disorder yang juga didapatkan dalam "social media addiction" adalah menyembunyikan kebiasaan adiksi mereka dari orang lain, perasaan untuk bebas, dan mental preoccupation atau mulai kesulitan membedakan kehidupan online dan offline. Lebih lanjut lagi kecanduan media sosial memiliki gejala sebagai berikut = mengalami penghayatan yang berlebihan dalam mengakses media sosial, moodswing, mengalami toleransi dalam intensitas penggunaan media sosial dan semakin meningkatan intensitasnya sepanjang waktu, apabila penggunaan media sosial dihentikan pengguna akan mengalami withdrawal syndrome, mulai muncul konflik interpsikis dan interpersonal yang mengganggu kegiatan sehari-hari, lalu muncul relapse atau kekambuhan apabila pengguna gagal mempertahankan untuk tidak mengakses media sosial (Kuss dan Griffiths, 2011). Meskipun belum semua ahli mengakui gejala kecanduan media sosial sebagai kelainan psikiatrik, namun 
gejala yang ditimbulkan kurang lebih sama dengan tipe kecanduan gadget lainnya seperti kecanduan video game.

Belum ditentukan kriteria diagnostik yang spesifik untuk kecanduan media sosial, namun kriteria diagnostik untuk kecanduan video game bisa diaplikasikan, antara lain = ketidakmampuan untuk mengontrol penggunaan media sosial, meningkatkan prioritas dalam mengakses media sosial secara ekstrem hingga mengganggu kegiatan sehari-hari, dan tetap menggunakan media sosial walaupun mendapatkan pengalaman buruk. Gejala-gejala ini harus muncul minimal 12 bulan kecuali apabila gejala yang ditemukan sangat parah (Kuss dan Griffiths, 2011). Penatalaksanaan yang bisa diberikan relatif sama dengan kasus-kasus kecanduan yang lain yaitu dengan memberikan terapi kognitif behavioral dan konseling untuk membantu penderita menemukan cara untuk mengatasi kecanduan mereka terhadap media sosial (NHS, 2018). Apabila individu sudah cenderung mengalami "social media addiction" maka akan susah untuk mengatasinya, maka diperlukan adanya tindakan preventif baik dari individu sendiri maupun lingkungan sekitar agar dapat terhindar dari kecanduan media sosial dengan membatasi akses media sosial sesuai kebutuhan saja dan menghindarkan diri dari kecemasan yang muncul dari interaksi sosial dalam media sosial.

Media sosial sekarang ini sudah menjadi sebuah komunitas tersendiri yang di mana di dalam komunitas tersebut individu mem-posting sesuatu baik itu gambar maupun tulisan. Dari setiap posting-an yang upload muncul reaksi yang berbeda-beda dari anggota komunitas lain, tentunya ada yang suka dan ada yang tidak suka. Respon dari individu yang tidak menyukai sesuatu ini nantinya akan berkembang menjadi suatu fenomena yang marak terjadi di dunia media sosial yaitu fenomena haters / hate speech (ujaran kebencian) karena tipe komunikasi menggunakan media sosial yang tidak mengharuskan individu bertatap muka memudahkan individu untuk memberikan komentar yang bersifat kritik maupun ujaran kebencian. Definisi oleh Council of Europe (2012) hatespeech dipahami sebagai "semua bentuk ekspresi yang menyebar, menghasut, mempromosikan atau membenarkan kebencian rasial, xenophobia, antisemitisme atau lainnya dalam bentuk kebencian berdasarkan intoleransi, termasuk: intoleransi nasionalisme agresif dan etnosentrisme, diskriminasi dan permusuhan terhadap kelompok minoritas, migran dan orang- orang asal imigran" (Jubany dan Roiha, 2015). Tanggapan tiap individu terhadap ujaran kebencian ini pun berbeda-beda.

Dalam psikologi, ada teori Stimulus-Respon (stimulus response theory) yang menyatakan bahwa organisme belajar dulu untuk mengasosiasikan stimulus awal dengan yang lainnya, stimulus yang berdekatan dan kemudian menanggapi stimulus kedua yang terkoordinasi dengan perilaku sebelumnya yang dipicu oleh stimulus awal. Masing masing individu mempunyai sifat dan karakteristik tertentu yang berbeda satu sama lainnya, dan hal ini tentunya yang menyebabkan terjadinya perbedaan tanggapan/respon dari tiap-tiap individu itu yang juga akan menimbulkan sikap dan perilaku yang berbeda-beda pula. Respon dalam hal ini dapat 
diasumsikan perupakan perubahan sikap yang terjadi pada komunikan berdasarkan stimulus atau rangsangan yang diterimanya. Teori ini dapat dianggap sebagai proses pertukaran atau perpindahan informasi. (Effendy, 2003). Pada teori ini Perbedaan Individu atau Individual Differences of Mass Communication yang dikemukakan oleh Melvin DeFleur menjelaskan bahwa pesan-pesan media yang berisi stimulus menghasilkan respon yang berbeda-beda dari kalangan khalayak. Hal ini disebabkan oleh perbedaan-perbedaan atau karakteristik tiap-tiap individu, seperti: usia, sikap, minat, pekerjaan, agama, dan sebagainya. "Pesan-pesan media berisi stimulus tertentu yang berinteraksi secara berbeda-beda dengan karakteristik pribadi dari anggota audiencenya". Perbedaan karakteristik individu tersebut dibedakan menjadi dua yaitu perbedaan fisik yang terdiri dari bentuk atau struktur tubuh, dan perbedaan psikis yang terdiri dari intelektualitas, kepribadian, minat, sikap, dan kebiasaan belajar. (Sandjaya dkk, 1994). Apabila ujaran kebencian dianggap sebagai stimulus, maka respon dari tiap individu akan berbeda-beda tergantung pada isi ujaran kebencian, minat individu, intelektualitas individu, kepribadian dan keadaan mental individu, dan masih banyak hal lain yang mempengaruhi. Oleh karena itu ujaran kebencian tidak bisa dianggap sebagai suatu hal yang ringan, karena beberapa individu dapat memberikan respon yang membahayakan terhadap ujaran kebencian yang ditujukan kepadanya di internet, contoh paling berbahaya adalah fenomena banyaknya artis yang bunuh diri akibat depresi menghadapi haters di media sosial. Menyikapi hal tersebut pemerintah Indonesia mengeluarkan UU ITE.

Undang-undang Informasi dan Transaksi Elektronik (disingkat UU ITE) atau Undangundang nomor 11 tahun 2008 adalah UU yang mengatur tentang informasi serta transaksi elektronik, atau teknologi informasi secara umum. UU ini memiliki yurisdiksi yang berlaku untuk setiap orang yang melakukan perbuatan hukum sebagaimana diatur dalam UndangUndang ini, baik yang berada di wilayah Indonesia maupun di luar wilayah hukum Indonesia, yang memiliki akibat hukum di wilayah hukum Indonesia dan/atau di luar wilayah hukum Indonesia dan merugikan kepentingan Indonesia (Kominfo, 2008). UU ITE ini diharapkan dapat menjadi pembatas agar fenomena haters tidak semakin menjadi-jadi karena pelaku ujaran kebencian di media sosial sudah dapat dikenai hukuman pidana. Berdasarkan incidental sampling yang peneliti lakukan terhadap 10 mahasiswa Fakultas Kedokteran Universitas Sebelas Maret didapatkan hasil 4 mahasiswa yang merasa lebih berhati-hati dalam menggunakan media sosial sejak diterbitkannya UU ITE dan 6 mahasiswa sisanya tidak merasa terancam oleh keberadaan UU ITE karena merasa tidak pernah mengeluarkan komentar atau postingan yang bersifat ujaran kebencian. Dari hal ini di ambil kesimpulan bahwa keberadaan UU ITE berfungsi sebagai ancaman bagi individu-individu yang intensitas penggunaan media sosialnya tinggi sehingga pernah atau sering melakukan aktivitas di media sosial yang bersifat ujaran kebencian, namun bagi individu yang menggunakan media sosial dengan intensitas 
rendah sehingga kemungkinan untuk melakukan aktivitas yang bersifat ujaran kebencian juga sedikit, keberadaan UU ITE tidak terlalu berpengaruh terhadap individu tersebut.

Sesuai dengan yang diajukan dalam Bab III bahwa terdapat beberapa variabel perancu dalam penelitian ini, yaitu usia dan jumlah uang saku/pendapatan per bulan. Pada tabel 4.5 didapatkan nilai hasil koefisien korelasi (r) dari hasil uji korelasi Spearman antara usia dan intensitas penggunaan media sosial yang dilakukan adalah 0,31 yang berarti berkorelasi positif cukup dan nilai signifikansi $(\mathrm{p})=0,814$ yang berarti kedua variabel tidak memiliki hubungan yang signifikan. Hal ini sesuai dengan penelitian yang dilakukan oleh Perrin (2015), pengguna media sosial tertinggi merupakan kelompok usia remaja akhir sampai dewasa muda (17-29 tahun). Pada penelitian ini ditemukan hasil yang tidak signifikan mungkin diakibatkan rentang usia yang tidak signifikan pula karena semua responden yang merupakan mahasiswa angkatan 2018 mayoritas berusia 19 tahun.

Sedangkan dalam hubungan antara jumlah uang saku/pendapatan per bulan dengan intensitas penggunaan media sosial WhatsApp, sesuai pada tabel 4.5, didapatkan nilai hasil koefisien korelasi (r) dari hasil uji korelasi Rank Spearman yang dilakukan adalah -0,68 yang berarti berkorelasi kuat negatif dan nilai signifikansi $(p)=0,604$ yang berarti kedua variabel tidak memiliki hubungan yang signifikan. Hal ini berarti walaupun uang saku/pendapatan per bulan dengan intensitas penggunaan media sosial aplikasi pesan singkat WhatsApp tidak memiliki hubungan yang signifikan, namun keduanya memiliki korelasi kuat tidak searah yang berarti semakin tinggi uang saku/pendapatan maka semakin rendah penggunaan media sosial aplikasi pesan singkat WhatsApp.

Hal ini sesuai dengan penelitian yang dilakukan oleh Andreassen et al. (2017), "Kecanduan menggunakan media sosial berhubungan kuat dengan usia yang masih muda, perempuan, tidak dalam suatu hubungan, tingkat pendidikan rendah, tingkat pendapatan rendah, memiliki ciri-ciri individu narsis dan kepercayaan diri rendah." Semakin rendah pendapatan seseorang maka akan semakin rendah kepercayaan dirinya, hal ini akan mendorong orang itu untuk mengakses media sosial lebih sering untuk menutupi kekurangannya. Namun hasil penelitian ini berlawanan dengan penelitian yang dilakukan oleh Perrin (2015), penggunaan situs jejaring sosial berkaitan dengan pendapatan yang lebih tinggi. Hal ini berkaitan dengan kemampuan untuk membeli paket internet per bulan dan ketersediaan perangkat yang memudahkan akses ke situs jejaring sosial.

\section{Kesimpulan}

Tingkat kepercayaan diri dan intensitas penggunaan media sosial aplikasi pesan singkat WhatsApp pada mahasiswa program studi pendidikan dokter Fakultas Kedokteran Universitas Sebelas Maret Surakarta Angkatan 2018 memiliki hubungan negatif yang kuat. 


\section{WACANA}

\section{Implikasi}

Terkait dengan hasil penelitian diatas, peneliti memiliki saran untuk penelitian selanjutnya yaitu perlunya diadakan penelitian yang lebih mendalam mengenai faktor-faktor yang mempengaruhi intensitas penggunaan media sosial setiap individu, antara lain usia, jenis kelamin, status ekonomi, tipe kepribadian, dan tujuan penggunaan media sosial, serta efek lebih lanjut dari kecanduan media sosial terhadap kesehatan mental. Peneliti juga menyarankan untuk dilakukan penelitian terkait faktor-faktor yang mempengaruhi tingkat kepercayaan diri, yaitu faktor internal yang terdiri dari konsep diri, harga diri, dan kondisi fisik. Serta faktor eksternal yang terdiri dari pendidikan, pekerjaan, lingkungan, dan pengalaman hidup.

Kontribusi Pengarang: "ASANA merencanakan dan membuat penelitian, serta menganalisis data, IY dan DN membimbing dan memberi arahan selama penelitian dan pembuatan naskah penelitian berlangsung. Semua pengarang membaca dan menyetujui hasil akhir dari naskah penelitian."

\section{Daftar Pustaka}

Adywibowo, Inge Pudjiastuti (2010). Memperkuat Kepercayaan Diri Anak melalui Percakapan Referensial. Jurnal Pendidikan Penabur - No.15/Tahun ke-9/Desember 2010. Jakarta. Hal: 37.

Agustiani, H. (2006). Psikologi Perkembangan, Suatu Pendekatan Ekologi, Kaitannya dengan Konsep Diri dan Penyesuaian Diri pada Remaja. Bandung : Refika Aditama.

Alsa, Asmadi dkk. (2006). Hubungan Antara Dukungan Sosial Orang Tua Dengan Kepercayaan Diri Remaja Penyandang Cacat Fisik. Semarang. Jurnal psikologi. No.1. 47-58. Hal: 48.

Alwisol. (2005). Psikologi Kepribadian. Malang: UMM Press.

American Psychiatric Association. (2013). Diagnostic and statistically manual of mental disorder: DSM-5. Washington, D.C: American Psychiatric Association.

Andarwati, S. R. \& Sankarto, B. S. (2005). Pemenuhan Kepuasan Penggunaan Internet Oleh Peneliti Badan Litbang Penelitian Bogor. Jurnal Perpustakaan Pertanian, 14 (1).

Andi, Mappiare. (1982). Psikologi Remaja. Surabaya: Usaha Nasional.

Andreassen, C.S., Pallesen, S., \& Griffiths, M.D. (2017). The relationship between addictive use of social media, narcissism, and self-esteem: Findings from a large national survey. Addictive Behaviors 64 (2017) Elsevier Ltd, 287-293.

Anthony, R. (1992). Rahasia Membangun Kepercayaan Diri. (terjemahan Rita Wiryadi). Jakarta: Binarupa Aksara.

APJII. (2017). Infografis Penetrasi dan Perilaku Pengguna Internet Indonesia. Asosiasi Penyelenggara Jasa Internet Indonesia. apjii.or.id: https://www.apjii.or.id/survei2017. 25 Juni 2019 (15.23).

Azwar, S. (1995). Sikap Manusia: Teori dan Pengkurannya, Edisi 2. Pustaka Pelajar, Yogyakarta. Azwar, Saifuddin. (2014). Metode Penelitian. Yogyakarta: Pustaka Pelajar. 
Baker, R.K \& White, K.M. (2010). Predicting adolescents' use of social networking sites from an extended theory of planned behavior perspective. Computers in Human Behavior. Vol. 26(6), pp. 1591-1597.

Barker V. (2009). Older Adolescents' Motivations for Social Network Site Use: The Influence of Gender, Group Identity, \& Collective Self-Esteem. http://www.liebertonline.com/doi/abs/10.1089/cpb.2008.0228. 12 September 2019 (19.32).

Boyd, D. M. \& Ellison. N. B. (2008). Social network sites: Definition, history and scholarship. Journal of Computer-Mediatied Communication, (13), 210-230.

Buffardi LE, Campbell WK. (2008). Narcissism and Social Networking Web Sites. Personal Soc Psychol Bull [Internet]. http://psp.sagepub.com/cgi/doi/10.1177/0146167208320061. 12 September 2019 (20.44).

Caplan, S. (2007). Relations among loneliness, social anxiety, and problematic Internet use. Cyberpsychology and Behavior 10 (2), 234-242.

Caplan, S. E. (2005). A Social Skill Account of Problematic Internet Use. Journal of Communication. International Communication Association.

Caplan, S. E. , Williams, D. , Yee, N. , (2009). Problematic Internet use and psychosocial well-being among MMO players. Computers in Human Behavior XX (2009) Elsevier Ltd.

Centi, P. J. (1995). Mengapa Rendah Diri. Yogyakarta: Kanisius. Hal: 33.

Corey, Gerald. (2007). Teori dan Praktek Konseling dan Psikoterapi. Bandung:PT. Refika Aditama.

Correa T, Hinsley AW, de Zúñiga HG. (2010). Who interacts on the Web?: The intersection of users' personality and social media use. Comput Human Behav [Internet]. Elsevier Ltd; 2010;26(2):247-53. http://linkinghub.elsevier.com/retrieve/pii/S0747563209001472. 12 September 2019 (23.45).

Dahlan, Sopiyudin M. (2016). Besar Sampel dalam Penelitian Kedokteran dan Kesehatan, Edisi 4. Epidemiologi Indonesia.

Drajat, Zakiah. (1995). Kesehatan mental. Jakarta. Cv. Haji masagung. Hal 25.

Ehrenberg, Alexandra \& Juckes, Suzanna \& White, Katherine \& Walsh, Shari. (2008). Personality and Self-Esteem as Predictors of Young People's Technology Use. Cyberpsychology \& behavior : the impact of the Internet, multimedia and virtual reality on behavior and society. $739-41$.

Enung Fatimah. (2006). Psikologi Perkembangan: Perkembangan Peserta Didik. Bandung: Pustaka Setia.

Fahmi. (2004). Penyesuaian Diri Remaja. Bandung : Karya Pustaka.

Feist, Jess dan Gregory J. Feist. (2010). Teori Kepribadian. Jakarta: Selemba. Santrock, J. W. (2007). Perkembangan Anak. Jakarta: Erlangga.

Frisnawati. A. (2012). Hubungan antara intensitas menonton reality show dengan kecenderungan prososial. Empathy vol. 1 : 50-54.

Gerungan, A,W. (2002). Psikologi Sosial. Bandung : Refika Aditama. 


\section{WACANA}

Ghifani, A. (2004). Percaya Diri Sepanjang Hari. Bandung : Mujahid.

Gunarsa, D.S. (2000). Psikologi Praktis, Anak, Remaja dan Keluarga. Jakarta: BPK Gunung Mulia.

Gunarsa. Singgih dan Ny. SD. Gunarsa. (1991). Psikologi Praktis Anak Remaja dan Keluarga. Jakarta. BPK Gunung Mulia.

Hakim, T. (2002). Mengatasi rasa tidak percaya diri. Jakarta : Puspa Swara.

Hakim, Thursan. (2002). Mengatasi Rasa Tidak Percaya Diri. Jakarta : Puspa Swara

Hanafebria. (2014). Media dan Teknologi Pilihan Sosial. http://mudazine.com. Diakses pada 24 Juni 2019.

Havighurst, Dinamika Robert. J. (1985). Human Development \& Education. Terjemahan Moh. Kasiran. Surabaya : Sinar Jaya.

Hofmann SG, Nadkarni A. (2013). Why Do People Use Facebook? NIH Public Access. 2013;52(3):243-9.

Horrigan, J.B. (2002). New Internet Users : What They Do Online, What They Don't Online and Implications For The Net's Future.

Horton RS, Reid C a., Barber JM, Miracle J, Green JD. (2014). An experimental investigation of the influence of agentic and communal Facebook use on grandiose narcissism. Comput Human Behav [Internet]. Elsevier Ltd; 2014;35:93-8. http://dx.doi.org/10.1016/j.chb.2014.02.038. 20 September 2019 (01.30).

Hoy M, Milne G. (2010). Gender differences in privacy-related measures for young adult Facebook users. J Interact Advert [Internet]. 2010;10(2):28-45. http://www.tandfonline.com/doi/abs/10.1080/15252019._2010.10722168. 20 September 2019 (01.45).

Hurlock, E. (1990). Psikologi perkembangan. Jakarta : Erlangga.

Hurlock. B. (2005). Psikologi Perkembangan Anak Jilid 2. Jakarta : Erlangga. Hal: 237.

Iswikharmanjaya, D., \& Agung, G. (2004). Satu Hari Menjadi Lebih Percaya Diri. Jakarta : Gramedia.

Jahanian, R. \& Seifury, Z.. (2013). The impact of internet addiction on students' mental health in technical and vocational colleges in alborz province. Middle East Journal of Scientific Research. 14. 1533-1538.

Kaur P. (2014). Between Social Networking Sites Usage Pattern And Motivations Behind Usage: A Study Of Generation Z 'A Digital Generation". Int J Appl Serv Mark Perspect [Internet]. 2014;3(2):996-1005.

http://www.pezzottaitejournals.net/index.php/IJASMP/article/view/1357. 20 September 2019. (18.54).

Keliat, B.A. (2000). Hubungan. Jakarta : Erlangga.

Kemp S. (2015). Southeast Asia Digital In 2015. Singapore. 
Kubey, R. W., Lavin, M. J., \& Barrows, J. R. (2001). Internet Use and Collegiate Academic Performance Decrements: Early Findings. Journal of Communication, 51(2), 366-382. doi:10.1111/j.1460-2466.2001.tb02885.x

Kurniasih, N. (2017). Internet Addiction, Lifestyle or Mental Disorder? A Phenomenological Study on Social Media Addiction in Indonesia. KnE Social Sciences, 2(4), 135-144. https://doi.org/10.18502/kss.v2i4.879. 20 September (17.33).

Kuss, D.J., \& Griffiths, M.D. (2011). Online social networking and addiction: A literature review of empirical research. International Journal of Environmental and Public Health, 8, 35283552.

Kusuma. (2005). Organisasi dan Motivasi : Dasar Peningkatan Produktivitas. Jakarta : Bumi Aksara.

Lauster, P. (2012). Tes Kepribadian. Terjemahan D. H. Gulo. Jakarta: Bumi Aksara.

Leman, Dr. Martin. (2002). Anakku. Martin Leman, M.D., DTM\&H. http://leman.or.id/anakku/daribayi.html. 18 Mei 2019 (22.10).

Lenhart A, Purcell K, Smith A, Zickuhr K. (2010). Social media and young adults. Pew Internet \& American Life Project. Universiy of Pennsylvania.

Lenhart, A. \& Madden, M. (2006). Online Dating. Pew Research Center.

Maslow, Abraham H. (1984). Motivasi dan Kepribadian. Seri Manajemen Cet. 1. PT. Pustaka Binaman Pressindo: Jakarta.

Moidfar, S., Habibpour Gatabi, K. (2011). 'Investigating the Phenomenon of the Internet Addictive Usage Among Adolescents and Youth (15-25 years of age) in the City of Tehran'. IAU International Journal of Social Sciences, 1(1), pp. 75-81.

Muchdi, Zulkifli L., (2009). Psikologi perkembangan. Bandung: PT REMAJA ROSDAKARYA. Hal: 63.

Mulyana, Deddy. (2007). Ilmu Komunikasi: Suatu Pengantar. Bandung : Remaja Rosdakarya.

0'Keeffe GS, Clarke-Pearson K. (2011). The impact of social media on children, adolescents, and families. Council on Communications and Media Pediatrics 127:800 - 4.

Olufadi Y. (2015). Social networking time use scale (SONTUS): A new instrument for measuring the time spent on the social networking sites. Telematics and Informatics. 2015;33(2):452471.

Orth, U., \& Robins, R. W. (2013). Understanding the link between low selfesteem and depression. Current Directions in Psychological Science, 22(6), 455-460.

Papalia, D. E., Old, S. W., Feldman, \& R. D. (2008). Human Development (terjemahan A. K. Anwar). Jakarta: Prenada Media Group.

Perrin, A. (2015). Social Networking Usage: 2005-2015. Pew Research Center.

Piaget, Jean, \& Barbel Inhelder. (2010). Psikologi Anak. Terj. Miftahul Jannah. Cet. 1. Yogyakarta : Pustaka Pelajar. 
Polpoke, Mardiyah. (2004). Pengaruh MLM (Multi Level Marketing) HD (High Desert) Terhadap Kepercayaan Diri Mahasiswa Selaku Distributor HD. Malang : Skripsi Fakultas Psikologi UIN.

Rahmat, Jalaludin. (2000). Psikologi Komunikasi. Bandung : Remaja Rosda Karya.

Ranggamukti, B. (2011). Hubungan antara kepercayaan diri dengan frekuensi mengakses situs jejaring sosial. Skripsi. Universitas Sanata Dharma, Yogyakarta, Indonesia. http://library.usd.ac.id. 27 September 2019 (22.15).

Raudatussalamah, Wilson. \& Purnama, D. B. (2007). Hubungan antara Pola Asuh Orangtua dengan Penyesuaian Diri Remaja Awal pada Masyarakat di Desa Pangkalan Jambi Kecamatan Bukit Batu Kabupaten Bengkalis. Jurnal Psikologi. Vol 3, No 2. Riau :Fakultas Psikologi ( UIN Sultan Syarif Kasim).

Rini, J. F. (2002). Memupuk Rasa Percaya Diri. http://www.e-psikologi.com/dewasa/161002.html. 25 September 2019 (21.00).

Riswana, Deni. (2019). Kelebihan dan Kekurangan WhatsApp. https://riswan.net/kelebihan-dankekurangan-whatsapp/. 28 Juni 2019 (12.03).

Robins, R. W., \& Trzesniewski, K. H. (2005). Self-Esteem Development Across the Lifespan. Current Directions in Psychological Science, 158-162.

Rochmawati, W. (2012). Perilaku Penmanfaatan Internet (Internet Utilization of Behavior). Skripsi thesis, Surabaya: Universitas Airlangga.

Rohmah, Nurul. (2017). Pengaruh Kepercayaan Diri dan Dukungan Sosial terhadap Penyesuaian Diri Mahasiswa Baru Teknik Informatika UIN Maulana Malik Ibrahim Malang. http://etheses.uin-malang.ac.id/9312/1/13410094.pdf. 28 Juni 2019 (13.14).

S. Gatot, B. Dewa, "Siaran Pers Tentang Riset Kominfo dan UNICEF Mengenai Perilaku Ana dan Remaja Dalam Menggunakan Internet". http://kominfo.go.id/index.php/content/detail/3834/Siaran+Pers+No.+17-PIHKOMINFO-2-

2014+tentang+Riset+Kominfo+dan+UNICEF+Mengenai+Perilaku+Anak+dan+Remaja+ Dalam+Menggunakan+Internet+/0/siaran_pers\#.VyozZPntmkp. 19 Mei 2019 (15.43).

Salim, Peter dan Salim, Yenny. (1991). Kamus Behasa Indonesia Kontemporer. Modern English Press: Jakarta.

Santrock, J. W. (2002). Life Span- Dovelopment (Perkembangan Masa Hidup). Edisi Kelima. Jakarta: Erlangga.

Santrock, J. W. (2003). Adolescence. Perkembangan Remaja (ed. 6). Jakarta: Erlangga.

Santrock, John. (1994). Child Development. New York McGraw.

Sarwono, S. (2011). Psikologi Remaja. Jakarta: PT. Rajagrafindo Persada.

Sativa, R.L. (2017). Berapa Lama Waktu Ideal Gunakan Gadget?. https://inet.detik.com/cyberlife/d-3398914/berapa-lama-waktu-ideal-gunakan-gadget. 15 Juli 2019 (21.56). 


\section{WACANA}

Sikape H.J. (2014). Persepsi Komunikasi pengguna media sosial pada blackberry messenger twitter dan facebook oleh siswa SMAN 1 tahuna. Journal Acta Diurna. Volume III, No. 3.

Sopiah, N., (2013). Faktor-faktor yang mempengaruhi penggunaan Media Facebook. Jurnal Ilmiah Matrik, pp.165-174.

Sparaggins, A. , (2009). Problematic use of social networking sites for college students : Prevalence, Predictors, and Association Well Being. Desertasi tidak diterbitkan. University of Florida.

Steinfield, C., Ellison, N.B., \& Lampe, C. (2008). Social capital, self-esteem, and use of online social network sites : A longitudinal analysis. Journal of Applied Development Psychology, 29; 434-445.

Stets, J. E., \& Burke, P. J. (2014). Self-Esteem and Identities. Sociological Perspectives,57, 409-433.

Subrahmanyam K, Reich SM, Waechter N. (2008). Espinoza G. Online and offline social networks: Use of social networking sites by emerging adults. J Appl Dev Psychol. 2008;29(6):42033.

Triastuti E, Primaldhi A, Rakhmani I. (2014). Profil Pengguna Internet Indonesia Tahun 2014. Jakarta: Asosiasi Penyelenggara Jasa Internet Indonesia

Valkenburg PM, Peter J, Schouten AP. (2006). Friend networking sites and their relationship to adolescents' well-being and social self-esteem. Cyberpsychol Behav. 2006;9(5):584-91.

We Are Social. (2018). https://www.slideshare.net/DataReportal/digital-2019-global-digitaloverview-january-2019-v01? ref=https://s3-ap-southeast

1.amazonaws.com/datareportal/digital/2019/wearesocial/en/digital-2019-wearesocialen-global-digital-overview.htm. 19 Mei 2019 (23.34).

Wendt B. (2014). The Allure of the Selfie: Instagram and the New Self-Portrait [Internet]. http://networkcultures.org/blog/ publication/no-08-the-allure-of-the-selfie-instagramand-the-new-selfportrait-brooke-wendt. 19 Mei 2019 (22.14).

Widiana, H. S., Retnowati, S., \& Hidayat, R. (2004). Kontrol Diri dan Kecenderungan Kecanduan Internet. Jurnal Humanitas: Indonesian Psychologycal Journal, No 1. p 6-16.

Wilson K, Fornasier S, White KM. (2010). Psychological predictors of young adults': use of social networking sites. Cyberpsychology, Behav Soc Netw [Internet]. http://www.ingentaconnect.com/content/adis/smd/2010/00000040/00000004/art000 01. 19 Mei 2019 (22.45).

Xu C, Ryan S, Prybutok V, Wen C. (2012). It is not for fun: An examination of social network site usage. Inf Manag [Internet]. http://dx.doi.org/10.1016/j.im.2012.05.001. 19 Mei 2019 (12.26). 